\title{
EFEK PENAMBAHAN JERAMI KACANG TANAH TERHADAP KUALITAS SILASE JERAMI JAGUNG
}

\section{The Effect of Adding Peanut Straw on Corn Straw Silage Quality}

\author{
Kartika Ekasari Z ${ }^{1}$, Aminuddin Saade ${ }^{1}$, dan Andi Ikhsan Wijaya ${ }^{2}$ \\ ${ }^{1}$ Politeknik Pembangunan Pertanian Gowa \\ ${ }^{2}$ Jurusan Peternakan, Politeknik Pembangunan Pertanian Gowa \\ e-mail: kartikaekasari@yahoo.co.id
}

Received: 18 Mei 2021; Accepted: 15 Juni 2021; Published: 25 Juni 2021

\begin{abstract}
ABSTRAK
Kekurangan pakan pada musim kering dapat diatasi dengan teknologi pengolahan pakan, salah satunya adalah fermentasi jerami jagung. Fermentasi jerami jagung adalah salah satu teknik pengawetan pakan atau hijauan pada kadar air tertentu melalui proses fermentasi oleh bakteri asam laktat yang disebut silase dan berlangsung di dalam tempat yang disebut silo atau kantung plastik. Kualitas penambahan jerami kacang tanah terhadap pembuatan silase jerami jagung. Kajian ini bertujuan untuk mengetahui perubahan Kualitas dengan penambahan jerami kacang tanah pada pembuatan silase jerami jagung. Metode Kajian disusun berdasarkan Rancangan Acak Lengkap (RAL) yang terdiri dari 4 Perlakuan dan 4 ulangan sehingga diperoleh 16 kemasan silase. Hasil analisis dengan menggunakan SPSS versi 25 jerami kacang tanah cukup efektif digunakan sebagai komponen atau campuran bahan silase jerami jagung, dengan komposisi molases 60 ml, EM-4 3 ml, dedak padi 5\%, untuk P0 tanpa jerami kacang tanah, P1:10 \% jerami kacang tanah, P2:20\% jerami kacang tanah dan P3:30\% jerami kacang tanah. Dari hasil uji organeoleptik dan Hasil Lab uji Kimia serat kasar dan protein kasar dapat disimpulkan bahwa Penambahan jerami kacang tanah pada pembuatan silase jerami jagung ditemukan yang terbaik adalah Kualitas Fisik P3 dan Kualitas kimia serat kasar dan protein kasar adalah P3, yaitu jerami Jagung 65\%, dedak 5\%, jerami kacang tanah 30\%.
\end{abstract}

Kata kunci: Silase, jerami jagung, jerami kacang tanah

\section{ABSTRACT}

Feed deficiency during the dry season can be overcome by implementing appropriate feed processing technology, such as fermentation of corn stover. Fermented corn stover is one technique to preserve feed or greens with a certain amount of water. It is processed by fermenting the stover by fermenting lactic acid, silage, in a particular plastic container called a silo. This study aims to examine quality changes of fermented corn stover by adding peanut straw onto the silage. The research method was a completely randomized design with four treatments and four repetitions, resulting in 16 silages in total. The four treatments are without peanut straw (P0), 10\% of peanut straw (P1), 20\%, and 30\% for P2 and P3, respectively. After analyzing the data by running it with SPSS version 25 , the result showed that peanut straw is useful ingredients to combine with corn stover. The compositions are $60 \mathrm{ml}$ of molasses, $3 \mathrm{ml}$ of EM4, 5\% of rice bran. Through organoleptic test and chemical test for crude protein and fiber, P3 was found to be the highest score in quality in terms of physical and chemical quality.

Keywords: silages, corn stover, peanut straw

\section{PENDAHULUAN}

Ternak ruminansia secara alami membutuhkan hijauan berupa rumput dan daundaunan. . Hijauan merupakan bahan pakan yang penting bagi ternak ruminansia dan harus tersedia terus menerus.Pada musim kemarau, tanaman hijauan yang dihasilkan sangat berkurang dalam jumlah dan kualitasnya. Penggunaan rumput sebagai sumber serat dan sumber energi pada ternak ruminansia bisa dikombinasikan ataupun 
digantikan dengan penggunaan limbah tanaman pertanian. Salah satu limbah yang berpotensi digunakan sebagai sumber serat adalah limbah tanaman jagung dan limbah tanaman kacang tanah. Pada saat musim panen ketersediaan limbah tanaman jagung dan limbah tanaman kacang tanah cukup tinggi sehingga bisa dimanfaatkan sebagai pakan ternak ruminansia.

Menurut Reksohadiprodjo (1994) dalam Trisnadewi, Dkk. 2007, jerami jagung merupakan sisa dari tanaman jagung setelah buahnya dipanen dan dapat diberikan pada ternak, baik dalam bentuk segar maupun dalam bentuk kering. Pemanfaatan jerami jagung sebagai pakan ternak telah dilakukan terutama untuk ternak sapi, kambing, domba.Jerami jagung merupakan hasil ikutan bertanam jagung dengan tingkat produksi mencapai 4-5 ton/ha. Upaya untuk mengatasi keterbatasan limbah tanaman jagung adalah dengan memberi perlakuan sebelum diberikan pada ternak atau melalui proses pengawetan sehingga kandungan nutrisinya dapat ditingkatkan.

Daun kacang tanah merupakan sumber protein dan zat kapur sehingga sangat baik untuk pakan ternak. Akan tetapi, pemberiannya kepada hewan ternak tidak boleh dalam keadaan segar (daun baru dipangkas) dan juga tidak boleh dalam jumlah berlebihan, sebab daun kacang tanah yang diberikan dalam keadaan segar dan berlebihan dapat menyebabkan sakit perut atau kembung (bloat) bagi hewan ternak yang memakannya (Cahyono, 2007)

Kekurangan pakan pada musim kering dapat diatasi dengan teknologi pengolahan pakan, salah satunya adalah fermentasi jerami jagung Fermentasi jerami jagung adalah salah satu teknik pengawetan pakan atau hijauan pada kadar air tertentu melalui proses fermentasi mikrobial oleh bakteri asam laktat yang disebut silase dan berlangsung di dalam tempat yang disebut silo atau kantung plastik.

Berdasarkan hasil identifikasi wilayah di

Desa Moncongloe, Kecamatan Manuju Kabupaten Gowa, Povinsi Sulawesi Selatan, Produksi limbah pertanian seperti jerami jagung sangat melimpah pada saat musim tanam dan musim hujan. Jerami jagung tersebut belum pernah diolah lebih lanjut Karena petani/peternak di daerah tersebut belum mengetahui tentang manfaat dari fermentasi dan indigofera belum banyak yang memanfaatkan untuk dijadikan sebagai bahan pakan ternaknya.Melihat dari keadaan tersebut sehingga menjadi motivasi bagi peneliti untuk mengambil judul tentang kualitas silase jerami jagung dengan penambahan jerami kacang tanah.

\section{METODE PENELITIAN}

\section{Tempat dan Waktu}

Kajian dilaksanakan pada bulan maret sampai dengan bulan mei 2020, dimana kegiatan kajian ini dilaksanakan di Kampus Politeknik Pembangunan Pertanian (POLBANGTAN) Gowa dan kegiatan penyuluhan dilaksanakan di kelompok tani Baji Pa'mai, Desa Moncongloe, Kecamatan Manuju Kabupaten Gowa, serta pengujian sampel dilaksanakan di laboratorium Universitas Hasanuddin (UNHAS) Makassar.

\section{Alat dan Bahan}

Alat yang digunakan dalam kajian yaitu parang, gunting, timbangan, gelas ukur, dan peralatan yang digunakan dalam kegiatan penyuluhan adalah kamera.

Bahan yang digunakan dalam kajian yaitu Jerami Jagung, Indigofera, dedak, air, molasses/gula dan EM4, kantong plastik, karet pengikat, polpen dan kertas label. Bahan yang digunakan dalam kegiatan penyuluhan yaitu peta singkap, kuesioner, folder, lembaran persiapan menyuluh (LPM), dan sinopsis.

\section{Metode}

Kajian ini dilaksanakan dengan menggunakan Rancangan Acak Lengkap (RAL) dengan 4 perlakuan dan 4 ulangan, sehingga terdapat 16 sampel yang akan diuji kualitasnya. Perlakuan silase jerami jagung adalah sebagai berikut :

$$
\begin{aligned}
\text { P0 = } & \text { Jerami Jagung } 95 \%+\text { Dedak Padi5\% } \\
\text { P1 = Jerami Jagung } 85 \%+\text { Dedak Padi } 5 \%+ & \text { Jerami Kacang Tanah } 10 \% \\
\text { P2 = } & \text { Jerami Jagung } 75 \%+\text { Dedak Padi } 5 \%+ \\
& \text { Jerami Kacang Tanah 20\% } \\
\text { P3 = } & \text { Jerami Jagung } 65 \%+\text { Dedak Padi } 5 \%+ \\
& \text { Jerami Kacang Tanah 30\% }
\end{aligned}
$$

\section{Prosedur Kerja}

Jerami jagung dan kacang tanah dicacah kurang lebih 3-5 cm menggunakan parang lalu dilayukan selama 12 jam pada ruangan terbuka lalu ditambahkan campuran EM4, air dan molasses. Bahan silase yang sudah dicampur 
secara homogen dengan bahan pengawet kemudian dimasukkan kedalam silo (kantong plastik ganda) dan ditekan serta divakum untuk mengeluarkan udara yang masih tersisa dalam kantong silo. Selanjutnya kantong silo diikat rapat menggunakan karet kemudian disimpan (diperam) diruangan dengan suhu ruangan $\pm 32^{\circ} \mathrm{C}$ pada tempat yang aman selama 21 hari.

Parameter yang diamati selama kajian berlangsung adalah kualitas fisik dan kimiawi silase, pengujian fisik dilakukan oleh 15 orang panelis yang paham dengan apa yang menjadi sampel kita yaitu silase jerami jagung dengan penambhan leguminosa indigofera. Adapun karakteristik panelis adalah sebagai berikut:

1) Panelis yang berjumlah 15 orang merupakan panelis yang telah mengetahui tentang silase;

2) Mengetahui kriteria silase yang baik;

3) Mempunyai kepekaan yang cukup baik

\section{Teknik Pengumpulan Data}

Data primer diperoleh langsung melalui kajian tentang kandungan protein kasar, serat kasar dan kualitas fisik silase jerami jagung dengan penambahan jerami kacang tanah hasil uji laboratorium dan uji organeoleptik oleh panelis, sedangkan data untuk penyuluhan diperoleh dari hasil observasi, dokumentasi dan wawancara langsung dengan responden menggunakan alat bantu kuisioner.

Data sekunder diperoleh melalui internet, jurnal penelitian, Kantor Desa Moncongloe dan kantor BPP Manuju, Kecamatan Manuju, Kabupaten Gowa, Provinsi Sulawwesi Selatan.

\section{Analisis Data}

Kajian ini bertujuan untuk mengetahui ada tidaknya perbedaan nyata setiap perlakuan terhadap peningkatan kualitas silase jerami jagung dengan penambahan leguminosa indigofera yaitu data yang diperoleh dari hasil uji organeoleptik dan uji laboratorium. Metode analisis data yang digunakan dalam kajian ini yaitu data yang diperoleh diolah dengan sidik ragam sesuai dengan Rancangan Acak Lengkap (RAL) dengan bantuan software SPSS versi 25. Data yang diperoleh dan hasil pengukuran akan diolah dengan menggunakan uji F (Sastrosupado 2000)

\section{Pelaksanaan Penyuluhan}

Kegiatan penyuluhan dilaksanakan dikelompok tani Baji Pa'mai, Desa Moncongloe, Kecamatan Manuju Kabupaten Gowa,yang diawali dengan persiapanmateri yang dilengkapi dengan Lembar Persiapan Menyuluh (LPM), Sinopsisdan kuesionersebagai alat ukur untuk mengetahui sejauh mana tingkat keberhasilan penyuluhan tentang materi yang disampaikan.

Media yang digunakan dalam pelaksanaan penyuluhan media cetak (folder), peta singkap, media elektronik laptop yang berisikan tentang informasi mengenai kualitas silase Jerami Jagung dengan penambahan jerami kacang tanah.

\section{Evaluasi Penyuluhan}

\section{Penetapan Tujuan Evaluasi}

Tujuan evaluasi dari pelaksanaan penyuluhan tentang perbaikan kandungan serat kasar dan kualitas fisik silase jerami jagung dengan penabahan leguminosa indigofera yaitu untuk mengukur tingkat pengetahuan, sikap dan keterampilan dalam mengadopsi materi penyuluhan yang disampaikan.

\section{Mempersiapkan Instrumen Evaluasi}

Pengukuran pengetahuan, sikap dan keterampilan responden tentang kualitas silase jerami jagung dengan penabahan leguminosa indigofera digunakan alat bantu berupa kuesioner sebanyak 15 pertanyaan meliputi aspek Pengetahuan, Keterampilan, dan Sikap (PKS) dengan 25 responden. Untuk mengukur tingkat pengetahuan 5 pertanyaan, tingkat sikap 5 pertanyaan, dan untuk tingkat keterampilan 5 pertanyaan. Dengan skor nilai $a=4, b=3, c=2$, dan $\mathrm{d}=1$.

\section{Populasi dan Sampel}

Populasi dalam kajian ini adalah Peternak yang bermukim di Desa Moncongloe, Kecamatan Manuju Kabupaten Gowa, yaitu sebanyak 796 petani/peternak yang tergabung dalam 12 kelompok tani.

Penentuan sampel kajian dismbil secar purposive sampling, dengan pertimbagan tertentu (sugiyono, 2017). Oleh karena populasi dalam kajian ini cukup besar yaitu sebanyak 796 
petani/peternak yang tergabung dalam 12 kelompok tani, maka yang diambil sebagai sampel sebanyak 25 petani/peternak yang tergabung dalam kelompok tani Baji Pa'mai. Alasan pemilihan kelompok tani Baji Pa'mai sebagai sampel karena sesuai kriteria dan kebutuhan kajian serta memiliki populasi ternak rumianansia lebih banyak diantara kelompok tani yang lain.

\section{Evaluasi Hasil Penyuluhan}

Agar mengetahui tingkat perkembangan responden peternak terhadap materi perbaikan kandungan serat kasar dan kualitas fisik silase jerami jagung dengan penambahan leguminosa indigofera yaitu melakukan pengukuran indikator menggunakan skala nilai (Rating scale) kemudian ditabulasi dan diolah menggunakan garis continuum (Padmowihardjo, 2002).

$$
\text { Tingkat PKS }=\frac{\text { Jumlah Jawaban }}{\text { Nilai Tertinggi }} \times 100 \%
$$

Efektivitas penyuluhan (ETP) dapat dihitung dengan menggunakan rumus:

$$
\mathrm{EP}=\frac{\mathrm{Ps}-\mathrm{Pr}}{\mathrm{N} 4 \mathrm{Q}-\mathrm{Pr}} \quad \mathrm{x} 100 \%
$$

Keterangan :

$$
\begin{array}{ll}
\mathrm{Ps} & =\text { Post test } \\
\mathrm{Pr} & =\text { Pree test } \\
\mathrm{N} & =\text { Jumlah responden } \\
4 & \text { = Nilai tertinggi } \\
\mathrm{Q} & =\text { Jumlah pertanyaan } \\
100 \% & =\text { Pengetahuan yang ingin dicapai } \\
\mathrm{Ps}-\mathrm{Pr} & =\text { Peningkatan pengetahuan } \\
\mathrm{N} 4 \mathrm{Q}-\mathrm{Pr} & =\text { Nilai kesenjangan }
\end{array}
$$

Maka nilai persentase efektifitas tingkat pengetahuan adalah, $<32 \%=$ Kurang efektif; 32 $-64 \%=$ Cukup efektif; $>64 \%=$ Efektif

\section{HASIL DAN PEMBAHASAN}

\section{Uji Organeoleptik}

Hasil uji organeoleptik dari 15 orang panelis tentang materi kualitas silase jerami jagung dengan penabahan leguminosa indigofera yang difermentasi selama 21 hari dilakukan uji fisik sebanyak 15 orang panelis terhadap 3 parameter yaitu Tekstur, Aroma dan Warna yang menjadi standar penilaian diberbagai perlakuan, Rata Rata Parameter Kualitas fisik Silase Jerami Jagung Dengan Penambahan Jerami Kacang Tanah dapat dilihat pada tabel 1 .

Tabel 1. Rata-rata parameter kualitas fisik silase jerami jagung dengan penambahan jerami kacang tanah

\begin{tabular}{clllll}
\hline \multirow{2}{*}{ No } & \multirow{2}{*}{ Parameter } & \multicolumn{5}{c}{ Perlakuan } \\
\cline { 3 - 6 } & & P0 & P1 & P2 & P3 \\
\hline 1 & Aroma & 2,5 & 2,3 & 3,1 & 3,3 \\
2 & Warna & 3,2 & 2,5 & 2,6 & 2,9 \\
3 & Tekstur & 2,3 & 2,4 & 2,8 & 3,1 \\
\hline
\end{tabular}

\section{Aroma}

Berdasarkan hasil pengamatan tabel 1 aroma silase jerami jagung dengan penambahan jerami kacang tanah menunjukkan parameter dari empat perlakuan yang memperoleh skor tertinggi $\mathrm{P} 3=3,3$, beraroma asam seperti cuka bila dibandingkan dengan P2, P1, dan P0. Saun dan Heinrichs (2008) Dalam Rukana, 2015, Mengatakan bahwa silase yang beraroma seperti cuka diakibatkan oleh pertumbuhan bakteri asam asetat (Bacili) dengan produksi asam asetat tinggi.

\section{Warna}

Warna memperoleh skor tertinggi terdapat pada perlakuan $\mathrm{P} 0=3,2$ yaitu warna hijau kekuning kuningan dibandingkan dengan P3, P2, P1. Menurut Saun dan Heinrichs (2008) Dalam Rukana, 2015, silase yang berkualitas baik akanmenghasilkan warna yang hampir menyamai warna tanaman atau pakan sebelum diensilasi,warna silase dapat menggambarkan hasil dari fermentasi,dominasi asam asetat akan menghasilkan warna kekuningan. 


\section{Tekstur}

Teksture memperoleh nilai tertinggi yaitu terdapat pada perlakuan $\mathrm{P} 3=3,1$ dimana tekstur silase lembut, tidak menggumpal dan segar dibandingkan dengan P2, P1, dan P0. Siregar (1996) menjelaskan bahwa secara umum silase yang baik mempunyai ciri-ciri tekstur yang masih jelas seperti asalnya.

\section{Uji Kimia}

\section{Serat kasar}

Serat kasar terdiri dari polisakarida yang tidak larut (selulosa dan hemiselulosa) serta lignin.Serat kasar tidak dapat dicerna oleh non ruminansia, tetapi merupakan sumber energi mikroba rumen dan bahan pengisi lambung bagi ternak ruminansia (Yulianto dan Suprianto, 2010). Nilai rataan serat kasar pada kajian ini dapat dilihat pada tabel 2 .
Tabel 2 menunjukkan bahwa rata-rata serat kasar silase jerami jagung yang tertinggi adalah perlakuan $\mathrm{P} 0$ dengan rata-rata serat kasar sebesar 41,77, kemudian diikuti oleh perlakuan P1 sebesar 36,12 kemudian P2 sebesar 33,85 dan yang terendah yaitu P3 hanya 28,80. Dari hasil kajian ini ditemukan perlakuan dedak 250 gram, jerami kacang tanah 1500 gram pada 3250 gram jerami jagung (P3) memeberikan hasil terbaik terhadap kandungan serat kasar pada silase jerami jagung. Penurunan serat kasar pada silase jerami jagung disebabkan karena terjadinya proses penguraian serat selama proses silase proses fermentasi oleh bakteri pengurai sehingga struktur serat kasar menjadi lebih sederhana. Sesuai dengan pendapat Antonius (2010), bahwa proses fermentasi dapat memutuskan ikatan lignin dan silika dengan selulosa dan hemiselulosa sehingga dapat menurunkan kandungan serat kasar dan lebih mudah dicerna.

Tabel. 2. Kandungan serat kasar

\begin{tabular}{cccccc}
\hline \multirow{2}{*}{ No } & \multirow{2}{*}{ Ulangan } & \multicolumn{4}{c}{ Perlakuan } \\
\cline { 3 - 6 } & & P0 & P1 & P2 & P3 \\
\hline 1 & I & 41,68 & 36,3 & 34,08 & 28,6 \\
2 & II & 41,77 & 35,99 & 33,85 & 28,4 \\
3 & III & 41,4 & 36,05 & 33,62 & 28,92 \\
4 & IV & 42,23 & 36,17 & 33,85 & 29,31 \\
& Total & 167,08 & 144,51 & 135,4 & 115,23 \\
& Rata rata & 41,77 & 36,12 & 33,85 & 28,80 \\
\hline
\end{tabular}

\section{Protein Kasar}

Protein dapat diperoleh dari pakan hijauan, dedak dan biji-bijian.Tanaman leguminosa lebih banyak kandungan protein daripada rumput.Kandungan protein daun lebih banyak dibandingkan tangkainya. Pada waktu tanaman menjadi tua, kadar protein dalam biji lebih banyak daripada bagian lainnya. Protein hewani merupakan zat pakan terbesar (75-80\% dari bahan kering), sedangkan sisanya adalah lemak, karbohidrat dan mineral (Yulianto dan Suprianto, 2010).Kandungan Protein Kasar dapat dilihat pada tabel 3 .

Tabel. 3. Kandungan protein kasar

\begin{tabular}{cccccc}
\hline \multirow{2}{*}{ No } & \multirow{2}{*}{ Ulangan } & \multicolumn{4}{c}{ Perlakuan } \\
\cline { 3 - 6 } & & P0 & P1 & P2 & P3 \\
\hline 1 & I & 6,43 & 9,25 & 9,95 & 10,36 \\
2 & II & 6,44 & 9,33 & 10,17 & 11,27 \\
3 & III & 7,22 & 8,49 & 9,71 & 10,7 \\
4 & IV & 6,67 & 9,43 & 10,46 & 10,75 \\
& Total & 26,76 & 36,5 & 40,29 & 43,08 \\
& Rata rata & 6,69 & 9,12 & 10,07 & 10,77 \\
\hline
\end{tabular}


Hasil uji kimia pada kualitas silase jerami jagung dengan penambahan leguminosa indigofera dapat diketahui protein tertinggi dari kajian ini terdapat pada perlakuan P3 kemudian diikuti P2 dan P1, selanjutnya yang terendah ditemukan pada perlakuan P0.Dari pengamatan tabel tersebut diketahui bahwa kanndungan protein pada legguminosa indigofera sangat tinggi dan dapat memepengaruhi kandungan silase jerami jagung yang ditambahkan indigofera.Sesuai dengan pendapat (Gutteridge \& Shelton 1994).Kandungan nutrisi Indigofera sp 2-3 kali lipat kandungan nutrisi biji-bijian serealia, sehingga memungkinkan digunakan sebagai bahan imbuhan (feed supplement) dalam memperbaiki produktivitas ternak

\section{Hasil Evaluasi Penyuluhan}

Evaluasi dilakukan untuk mengukur pengetahuan, sikap dan keterampilan peternak tentang Kualitas Silase Jerami Jagung Dengan Penambahan Jerami kacang tanah. Evaluasi yang dilakukan terdiri dari evaluasi awal dan evaluasi akhir. Materi penyuluhan dilakukan dengan menggunakan rating scale kemudian ditabulasi dan diolah dengan menggunakan garis continuum. Tinggi rendahnya tingkat pengetahuan responden dapat ditentukan melalui jawaban responden dari tiap-tiap pertanyaan dalam evaluasi awal dan evaluasi akhir. Dengan responden anggota kelompok tani Baji Pa'mai sebanyak 25 orang. Hasil evaluasi penyuluhan diharapkan dapat menggambarkan tercapai atau tidaknya program penyuluhan sebagai gambaran hasil kegiatan penyuluhan yang telah dilaksanakan.

Selanjutnya hasil evaluasi awal dan evaluasi akhir ditabulasi untuk mengetahui tingkat pengetahuan, sikap dan keterampilan responden berdasarkan kategori penilaian yang dicapai.Hasil rekapitulasi digunakan untuk mengetahui sejauh mana tingkata perubahan nilai presentase. Hasil rekapitulasi dapat dilihat pada Tabel 4. Hasil tabel 4 dapat diketahui bahwa perubahan dari evaluasi awal untuk tingkat pengetahuan yaitu 187 atau $37,4 \%$, untuk keterampilan yaitu 172 atau $34,4 \%$ dan sikap yaitu 172 atau $34,4 \%$.

Tabel 4. Rekapitulasi hasil penilaian tingkat perubahan pengetahuan, keterampilan, dan sikap Responden Kelompok Tani Baji Pa'mai, Desa Moncongloe, Kecamatan Manuju Kabupaten Gowa

\begin{tabular}{ccccccccc}
\hline \multirow{2}{*}{ No } & \multirow{2}{*}{ Deskripsi } & \multirow{2}{*}{ Nilai Max } & \multicolumn{3}{c}{ Nilai yang Diperoleh } & \multicolumn{3}{c}{ Perubahan } \\
\cline { 4 - 9 } & & & E. Awal & $\%$ & E. Akhir & $\%$ & Nilai & $\%$ \\
\hline 1 & Pengetahuan & 500 & 138 & 27,6 & 325 & 65 & 187 & 37,4 \\
2 & Keterampilan & 500 & 163 & 32,6 & 373 & 74,6 & 210 & 42 \\
3 & Sikap & 500 & 194 & 38,8 & 366 & 73,2 & 172 & 34,4 \\
\hline
\end{tabular}

\section{Efektivitas Penyuluhan}

Evaluasi penyuluhan merupakan salah satu bagian untuk menentukan efektifitas dan dampak penyuluhan sesuai dengan tujuan yang ingin dicapai. Aspek yang diukur dalam pelaksanaan penyuluhan adalah efektivitas program penyuluhan dan perubahan perilaku responden. Efektivitas penyuluhan menggunakan rumus Ginting (1991):

$$
\begin{aligned}
\text { ETP } & =\frac{\text { Ps }-\mathrm{P}-\mathrm{r}}{(\mathrm{n} .4 . \mathrm{Q})-\mathrm{Pr}} \times 100 \% \\
& =\frac{1064-495}{(25.4 .15)-495} X 100 \% \\
& =\frac{569}{1005} \times 100 \%=56.61 \%
\end{aligned}
$$

Keriteria penilaian yaitu $<33,33 \%=$ Kurang efektif; $33,33-66,66 \%=$ Cukup efektif; $>66,66 \%=$ Efektif.
Berdasarkan kriteria penilaian yang telah ditentukan, maka pelaksanaan penyuluhan yang telah dilakukan termasuk kategori cukup efektif yaitu $56,61 \%$. Adanya kegiatan penyuluhan maka diharapkan pengetahuan, ketrampilan dan sikap peternak dapat ditingkatkan.

\section{KESIMPULAN}

Kesimpulan hasil kajian kualitas kimia dan kualitas fisik jerami jagung dengan penambahan jerami kacang tanah adalah sebagai berikut:

1. Hasil uji organoleptik pada menunjukkan bahwa penambahan jerami kacang tanah pada silase jerami kacang tanah dengan konsentrasi 10\%, 20\%, dan 30\%, memberikan pengaruh terhadap kualitas fisik silase khususnya pada tekstur dan aroma. 
Sedangkan hasil uji proksimat menunjukkan P3 memiliki nilai rata-rata terbaik pada parameter yang diuji yaitu serat kasar $28,80 \%$ dan protein kasar $10,77 \%$.

2. Hasil evaluasi penyuluhan di kelompok tani Desa Moncongloe Kecamatan Manuju Kabupaten Gowa, memberikan perubahan pengetahuan dari $27,6 \%$ menjadi $65 \%$, perubahan keterampilan dari $38,8 \%$ menjadi $73,2 \%$, dan sikap dari $32,6 \%$ menjadi $74,6 \%$ serta efektivitas penyuluhan adalah berada pada tingkat cukup efektif.

\section{DAFTAR PUSTAKA}

Antonius, 2010. Pengaruh Pemberian Jerami Padi Terfermentasi Ter-hadap Palatabilitas Kecernaan Serat Dan Digestible Energy Ransum Sapi. Seminar Nasional Teknologi Peternakan dan Veter-iner. 224-228

Cahyono B. 2007. Kacang Tanah. Semarang : Renika Cipta.
Sastrosupadi, A. 2000.Rancangan Percobaan Praktis Bidang Pertanian. Buku.Kanisius. Malang. 267 P.

Ginting, E. 1991.Metode Kuliah Kerja Lapang Universitas Brawijaya, Malang

Saun, R.J.V., and A.J.Heinrich. 2008. Trouble shooting silage problem. InProceedingsof the Mid-Atlantic Conference.

Siregar, S.B. 1996. Pengawetan Pakan Ternak. Penebar Swadaya, Jakarta.

Sugiyono, 2017.Metode Penelitian Kuantitatif, Kualitatif, dan $R \& D$. Bandung: Alfabeta

Trisnadewi, A. A. A. S., I G. L. O. Cakra., Dan I W Suarna.2007. Kandungan Nutrisi Silase Jerami Jagung Melalui Fermentasi Pollard Dan Molases. Majlah Ilmiah Peternakan.Volume 20 No.2 : 55. Diakses pada tanggal 8 maret 2020.

Yulianto, P. dan C. Suprianto.2010. Pembesaran Sapi potong Secara Intensif. Penerbit Swadaya. Jakarta. 